International Journal of Social Science And Human Research

ISSN(print): 2644-0679, ISSN(online): 2644-0695

Volume 04 Issue 11 November 2021

DOI: $10.47191 / \mathrm{ijsshr} / \mathrm{v} 4-\mathrm{i} 11-49$, Impact factor-5.586

Page No: 3393-3403

\title{
The Influence of Google Search Intensity on the Stability of the Indonesian Capital Market in the Perspective of the Defense Economy
}

\author{
Darnis $^{1}$, Guntur Eko Saputro ${ }^{2}$, Ikhwan Syahtaria ${ }^{3}$ \\ ${ }^{1}$ Student of Defense Economics Department, Indonesia Defense University, Indonesia \\ ${ }^{2,3}$ Lecture of Defense Economics Department, Indonesia Defense University, Indonesia
}

\begin{abstract}
This study aims to determine the Influence of Google Search Intensity on the Stability of the Indonesian Capital Market, as well as looking at the defense and security aspects, especially the economy. The research sample is the shares of the banking sector companies listed on the Indonesia Stock Exchange for the 2016-2018 period. The independent variable used in this study is the Abnormal Search Volume Index. The control variables used are Volatility, and Abnormal Trading Volume Lagged. The dependent variable used is Abnormal Trading Volume. The sampling method used in this study used a purposive sampling technique. Obtained the number of samples as many as 18 companies. The analysis technique used in this research is panel data regression. The results of this study indicate that the intensity of Google searches using the ASVI proxy has a significant positive effect on the stability of the stock represented by Abnormal Trading Volume. This illustrates that the use of Google search intensity data can be used as a reference in making defense policies against non-military threats, especially the stability of the Indonesian Capital Market.
\end{abstract}

KEYWORDS: Capital Market Stability, Google Intensity, Stock Volatility, Economic Defense

\section{INTRODUCTION}

\section{I.1 Background of the Problem}

With the development of information and communication technology, along with the current pace of globalization, crimes are increasingly developing across national borders and are more of a non-military threat. Included in the category of such crimes are economic crimes which are often expressed in various terms, including economic crimes, crime as business, business crimes and abuses of economic power. The capital market or stock exchange is a type of market where investors meet to sell or buy securities or securities. The capital market has a strategic role in national development and therefore it is necessary to maintain the stability of the capital market from the threats of non-military crimes. Crime in the capital market is one form of crime that is currently developing. In capital market activities, the known forms of crime are grouped into 2 types, namely fraud and market manipulation. What is meant by fraud, according to the Capital Market Law Article 90 letter c is: "Making an untrue statement regarding material facts or not disclosing material facts so that the statements made are not misleading regarding the circumstances that occurred at the time the statement was made with the intention of benefiting or avoiding harm to oneself. or other parties or with the aim of influencing other parties to buy or sell securities".

The shift in investor behavior patterns supported by technological developments and digitalization greatly affects the pattern of information channels, this also has implications for trading in the capital market. Changes in the search for information related to stocks from print media to electronic media simultaneously make changes to the character of investors in seeking information to invest. Investors who feel they have limited information on a stock will search through the internet and investors are also very easy to get information on a stock that attracts investors' attention.

The availability of information and the rapid movement of information will affect the investment decisions of investors. Investor decisions based on electronic media information will affect the movement of stock trading volumes. Market reactions that occur as a result of an information can describe the activities of investors (Fang \& Peress, 2009). Stock trading volume can be used as a benchmark for the liquidity of a stock. With the increase in stock trading volume, it means that shares traded in the secondary market will be more liquid. Liquidity is the ease of buying and selling a stock

When viewed from access to information, the number of internet users in Indonesia in 2014 reached $17.1 \%$ until 2016 increased to $20.4 \%$, and became 54.7\%, equivalent to 143.26 million people in 2018 (Association of Service Providers) Indonesian Internet). Based on these data illustrates that Indonesia has experienced significant growth in internet access and information. Based 


\section{The Influence of Google Search Intensity on the Stability of the Indonesian Capital Market in the Perspective of the Defense Economy}

on the statcounter website, it was found that in the period from 2016 to 2018 , Google became the most frequently used search engine with a market share of $91.89 \%$. This is very far from other search engines such as yahoo, bing and Ask Jeeve, with the dominance that is owned by Google, the business world also relies a lot and competes to become the top ranking in the Google search engine.

Search intensity using the google search volume index proxy can reveal and quantify investor interest. Several reasons that can make the Google search volume index as an appropriate benchmark in measuring search intensity refer to previous research studies, namely: 1) Internet users generally use search engines to collect information and as explained above Google is the most frequently used search, and 2) The search carried out is a measure of the intensity of the search that is proven to be real and valid. Every search made on the Google platform will be automatically quantified into the google search volume index data.

In this study, the author will focus on discussing the effect of the search intensity projected by the google search volume index on the liquidity that moves in the banking sector listed on the Indonesia Stock Exchange in the period 2016 - 2018 . There are several reasons the author took the banking sector, namely: 1) There was a slowdown in the growth of the banking sector in the period 2013 to late 2014 and again experienced growth in 2015 to 2018. Although the slowdown and growth of the banking sector is inseparable from the influence of the global economy, there are factors that the authors see as supporting growth, such as ease of access. banking and banking digitalization. The effect of banking digitization is the emergence of electronic money. In May 2016, Bank Indonesia said that 38.35 million pieces of electronic money had circulated, 2) There was competition with financial technology platforms, which forced conventional banks to make innovations in facing the competition. In 2016 the Financial Services Authority issued a regulation No.77/POJK.01/2016 regarding digital technology-based lending or known as Peer Two Peer lending (P2P). The challenge is not limited to P2P lending because in 2017, fintech startups have targeted mutual fund investment services, purchasing insurance products, remittances, and up to wealth management. Facing competition with conventional fintech banks, they are required to be more open in information about products that can meet the needs of consumers based on technology and digital. 3) Banking is a service company that must be able to maintain the level of consumer confidence, because it is related to managed customer funds. One way to maintain the level of customer trust is to maintain information related to the company so that it is always seen as positive by stakeholders. The sensitivity of banking to information makes banks a worthy object for research.

\subsection{Problem Formulation}

How does the intensity of searching with Google affect the stability of the capital market as seen from the stock liquidity of banking sector companies listed on the Indonesia Stock Exchange for the 2016-2018 period from a defense economic perspective?

\subsection{Research purposes}

Knowing the effect of the intensity of searching with Google on the stability of the capital market as seen from the stock liquidity of banking sector companies listed on the Indonesia Stock Exchange for the 2016-2018 period from a defense economic perspective?

\subsection{Benefits of research}

\subsubsection{For Academy}

This research can provide knowledge and broaden insight, especially about the effect of search intensity projected by Google search volume index on capital market stability as proxied by stock liquidity. As well as providing an understanding of non-military threats to the capital market sector and being able to anticipate crimes that will occur in the capital market.

\subsubsection{For Investors}

This research can be useful to provide input, in making investment decisions by considering the value of the Google search volume index to see the direction of stock movements.

\subsubsection{For Companies}

This research can be useful to provide input to companies in managing information to attract investors' attention, changes in information channels from print to digital make Google search volume index provide an overview to companies about trends in investor behavior.

\section{LITERATURE REVIEW}

\section{II.1 Non-Military Threats}

Non-military defense is a force that within the framework of deterrence is built and developed to achieve national security standards in the fields of ideology, politics, economy, socio-culture, psychology, and technology. Non-military threats have different dimensions of handling from the approach to handling military threats. In facing the condition of the state facing actual threats in the form of non-military threats, the state defense system is arranged in a non-military defense layer as the main element to take countermeasures with a non-military approach by empowering ideological, political, economic, psychological, socio-cultural, information and technology instruments, as well as law and human rights. The core of non-military defense is non-physical defense that does not use weapons as is done by the military defense layer, 


\section{The Influence of Google Search Intensity on the Stability of the Indonesian Capital Market in the Perspective of the Defense Economy}

\section{II.2 Stock Liquidity}

Stock liquidity can be seen from the trading volume that occurs in a stock. Stock trading volume is the ratio between the number of shares traded at a certain time with the number of shares outstanding at a certain time (Husnan et al., 2005). Stock trading volume is often used to measure the liquidity of a stock, which is related to investor interest in a related stock instrument.

Bade and Hirth, (2016) argue that liquidity refers to the size of the number of transactions of a stock in the capital market in a certain period. The higher the transaction frequency of the shares, the higher the liquidity of the shares. Even on the Indonesia Stock Exchange, ratings have been made for 45 companies that have the highest stock liquidity, known as LQ45 ratings.

According to previous research by Kim et al., (2018) Abnormal trading volume is a standardization of stock trading volume which represents stock liquidity. The higher the liquidity of a stock, it means that investors' interest in the stock is also higher.

Information :

$$
\operatorname{ATV}_{t}=\frac{\operatorname{TV}_{\mathrm{t}}-\frac{1}{12} \sum_{\mathrm{i}=1}^{12} \mathrm{TV}_{\mathrm{t}-\mathrm{i}}}{\sigma T V_{t-12}}
$$

ATVt $=$ Abnormal monthly trading volume in period $\mathrm{t}$

$\mathrm{TVt}=$ Monthly trading volume in period $\mathrm{t}$

$\frac{1}{12} \sum_{\mathrm{i}=1}^{12} \mathrm{TV}_{\mathrm{t}-\mathrm{i}}=$ Average trading volume over the previous 12 month period

$\sigma T V_{t-12}=$ Standard deviation of Trading Volume over the previous 12 month period

\section{II.3 Google Search Intensity}

Investor attention is the way in which a person actively processes a limited amount of information, from the large amount of information available through one's senses, stored memories and other cognitive processes (De Weerd 2003). by focusing only on what he finds interesting and ignoring other information outside of that. When investors have to make investment decisions, considering that there is a large amount of information available and limited attention, investors must be selective in processing information, and gathering information about the company of interest obtained from both internal (eg, previous experience) and external sources (eg. Example: advertisements, brochures,

Google search volume indexfilter their data collection from sources namely Website, Youtube, News, Images and Google Shopping. Google Search Volume Index can filter searches in several categories. In this study, the category used in screening is "Business and Industrial". The formula for calculating the abnormal search volume index, the author adapts from research conducted by Kim et al., (2018), namely:

$$
\operatorname{ASVI}_{t}=\frac{\operatorname{SVI}_{\mathrm{t}}-\frac{1}{12} \sum_{\mathrm{i}=1}^{12} \mathrm{SVI}_{\mathrm{t}-\mathrm{i}}}{\sigma S V I_{t-12}}
$$

Information :

$$
\begin{array}{ll}
\text { ASVIt } & =\text { Monthly Abnormal Search Volume Index in period t } \\
\text { SVIt } & =\text { Monthly Search Volume Index in period } \mathrm{t} \\
\frac{1}{12} \sum_{\mathrm{i}=1}^{12} \mathrm{SVI}_{\mathrm{t}-\mathrm{I}} & =\text { Average Search Volume Index over the previous } 12 \text { month period } \\
\sigma S V I_{t-12} & =\text { Standard deviation of Search Volume Index over the previous } 12 \text { month period }
\end{array}
$$

\section{II.4 Volatility}

Volatility is a statistical measurement for fluctuations in stock prices over a certain period. Volatility in financial markets is very important in terms of risk management, asset pricing, and stock portfolios. Research conducted by Xu et al., (2018) on the Shanghai Composite Index of the Chinese stock market, found that the volatility of a stock significantly affects stock liquidity and liquidity also affects volatility. The same thing was also found in research conducted on the Canadian stock market by (Gold et al., 2017).

Volatility means that there is a shock that occurs in the stock, in the sense that there is an up and down price in the market. The stock price is a reflection of the issuer's decision to invest in funding (including dividend policy) and asset management. The more people who buy the related stock instrument, the share price of the issuer tends to rise. Conversely, the more people who sell the shares of an issuer, the share price of the issuer will move down.

For the measurement of volatility in this study, the authors adapted the formula used by Daigler and Wiley, (1999) which was adapted from Garman and Klass, (1980):

Volatility $=0.5[\ln ($ Hit $)-\ln ($ Lit $)] 2-[2 \ln (2)-1][\ln ($ Oit $)-\ln ($ Cit $)] 2$ Information : 


\section{Defense Economy}

\begin{tabular}{|c|c|}
\hline Volatility & $=$ Monthly volatility in period $\mathrm{t}$ \\
\hline Hit & $=$ The highest price of stock $\mathrm{i}$ in period $\mathrm{t}$ \\
\hline $\mathrm{Li}$ & $=$ The lowest price of stock $\mathrm{i}$ in period $\mathrm{t}$ \\
\hline cit & $=$ closing price of stock $\mathrm{i}$ in period $\mathrm{t}$ \\
\hline Oit & $=$ Opening price of share $\mathrm{i}$ in period $\mathrm{t}$ \\
\hline $\ln$ & $=$ Natural Logarithm \\
\hline
\end{tabular}

\section{II.5 Abnormal trading volume Lagged -1}

In economic statistics, the attachment of a variable to past effects or time intervals can be included in a regression model, the reaction or influence of past conditions is also called the distributed lag model. Research by Bijl et al., (2016) uses abnormal trading volume data from the previous 8 weeks as a control variable in viewing the abnormal trading volume that is happening now. In research using panel data, the authors see the need to include a control variable in the form of data one month earlier (lagged-1).

Trading activity in the money market in the previous month not only affects trading volume, but also stimulates investors to search on Google. This makes the authors more interested in including lagged-1 into the research model as a control variable. The formula used is adapting the research of Kim et al., (2018), namely:

Information :

$$
\operatorname{ATV}_{t-1}=\frac{\operatorname{TV}_{t-1}-\frac{1}{12} \sum_{i=1}^{12} \operatorname{TV}_{t-i}}{\sigma T V_{t-12}}
$$

ATVt-1 = Abnormal monthly trading volume in period $\mathrm{t}-1$

TVt-1 = Monthly trading volume in period $\mathrm{t}-1$

$\frac{1}{12} \sum_{\mathrm{i}=1}^{12} \mathrm{TV}_{\mathrm{t}-\mathrm{i}}=$ Average trading volume over the previous 12 month period

$\sigma T V_{t-12}=$ Standard deviation ttrading volume during the previous 12 month period

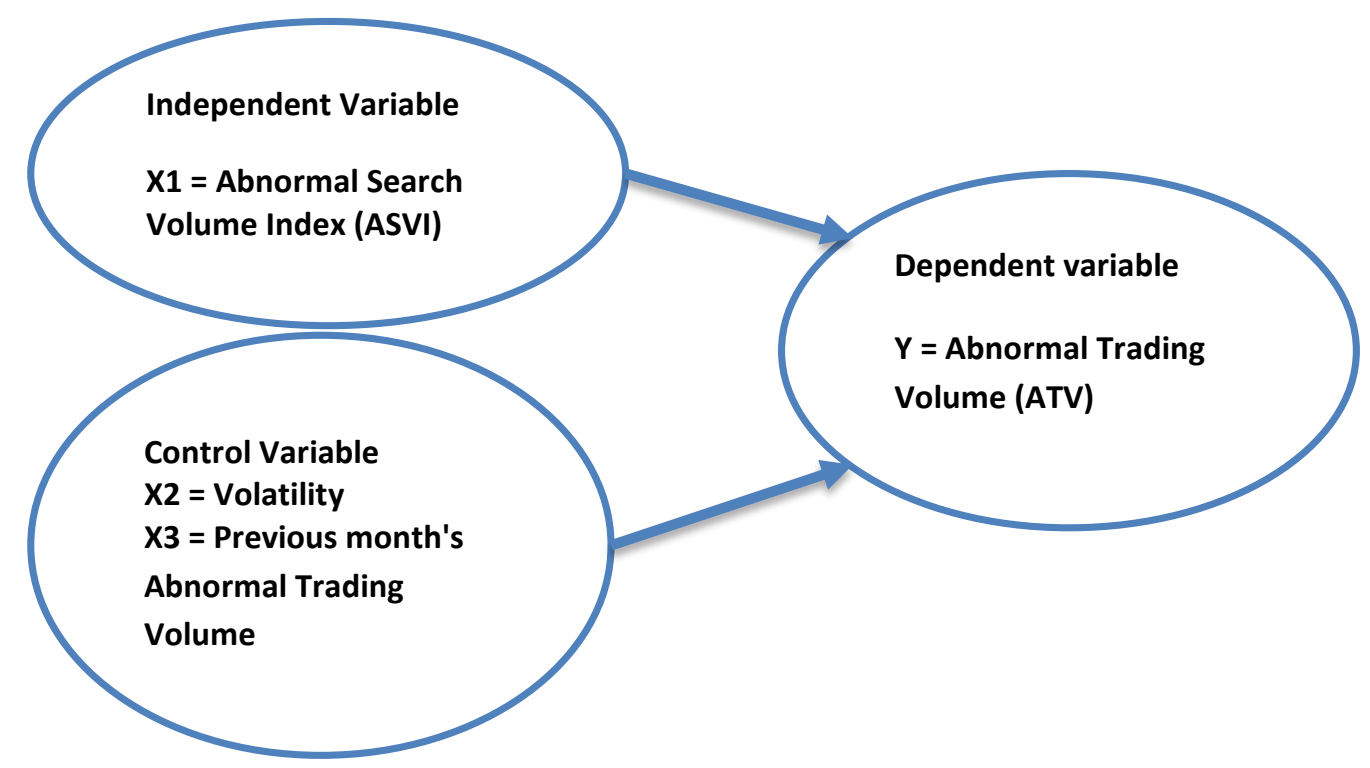

Figure II. 1

Research Model

Source: Data processed by researchers (2021)

H1: Search intensity with Google as proxied by abnormal search volume index has a positive and significant effect on capital market stability as proxied by stock liquidity in the banking industry on IDX stocks in 2016-2018

\section{METHODOLOGY}

\section{III.1 Object and Scope of Research}

In this study, the object of this research is the intensity of searches on Google on the liquidity of banking stocks. The data used in this study is secondary data obtained from historical stock reports on yahoo finance and financial reports on www.idx.co.id. For stock search intensity data obtained from historical data on google trend. 


\section{III.2 Research Method}

In this study is associative, namely to determine the effect or relationship between variables. The analysis used in the form of quantitative analysis (statistics) because the data used in the form of numbers. Observations made in this study consisted of several companies (cross section) and over a period of several years (time series), therefore the regression used was panel data regression. The data that has been obtained from official websites and credible sources will then be analyzed quantitatively and processed using the eviews10 program.

\section{III.3 Method of Determination of Population and Sample}

\section{a) Population}

The population is a generalization area consisting of objects/subjects that have the qualities and characteristics set by the researcher to be studied and concluded (Sugiyono, 2012). The population used in this study are banking sector companies listed on the Indonesia Stock Exchange for the 2016-2018 period, totaling 43 companies.

b) Sample

The sample is part of the number and characteristics possessed by a predetermined population (Sugiyono, 2012). For sampling in this study using non-probability sampling because each member of the population does not have the same opportunity to be sampled. The type of non-probability sampling used is purposive sampling, namely the technique of determining the sample with considerations that are in accordance with the research objectives so that it can get the right sample. As for what will be used by researchers in selecting the sample are as follows: 1) banking sector companies listed on the Indonesia Stock Exchange in the 2016-2018 period, 2) companies that provide information related to the object of research, in the form of financial data, stock prices, and trading volume during 2016-2018,

\section{III.4 Research Model}

The regression model can be made as follows:

$$
\text { ATV t,i = i + } 1 \text { ASVI t,i + } 2 \text { VOL t,i + 4ATV t-1,i + }
$$

Information :

ATV $\mathrm{t}, \mathrm{i}=$ Abnormal trading volume of company $\mathrm{i}$ period $\mathrm{t}$

$\mathrm{i}=$ Firm constant $\mathrm{i}$

= Regression coefficient

ASVI $\mathrm{t}, \mathrm{I}=$ Abnormal search volume index of company $\mathrm{i}$ in period $\mathrm{t}$

VOL $\mathrm{t}, \mathrm{i}=$ Stock volatility of company company i period $\mathrm{t}$

ATV $\mathrm{t}-1, \mathrm{I}=$ Abnormal trading volume of company $\mathrm{i}$ in period $\mathrm{t}-1$

$=$ Error

\section{IV.RESEARCH RESULTS AND DISCUSSION}

IV. 1 Descriptive Analysis

Table IV.1 Descriptive Test Results

Date: 21/10/21 Time: 21:40

Sample: 2016M01 2018M12

\begin{tabular}{|c|c|c|c|c|}
\hline & ATV & ASVI & VOLATILITY & ATV_T_1 \\
\hline mean & 0.572326 & 0.681659 & 0.013339 & -0.511280 \\
\hline median & -0.340088 & 0.380480 & 0.006074 & -0.373378 \\
\hline Maximum & 180.5600 & 9.956615 & 0.237947 & 3.501738 \\
\hline Minimum & $-16,01876$ & -4.052070 & 0.000000 & $-15,94490$ \\
\hline Std. Dev. & 11.07545 & 1.656232 & 0.026226 & 2.250062 \\
\hline Observations & 648 & 648 & 648 & 648 \\
\hline
\end{tabular}

\section{a. Liquidity}

Liquidity is measured using the abnormal trading volume (ATV) proxy, from the results of table IV.1 the average value is 0.572. The maximum value of 180.560 obtained by Bank Mega in January 2017, this occurred because the trading volume of Bank Mega's shares increased very significantly to 3,935,200 shares from the average value of the previous 12 months which was only 11,183 shares. As for the minimum value of $-16,019$ obtained by Bank Mega in September 2016, this was due to a decrease in trading volume in Bank Mega's shares in September which was only 400 shares. The decline in stock trading activities of Bank 


\section{Defense Economy}

Mega was influenced by audit activities carried out by the Financial Services Authority (OJK) on market risk and liquidity risk in early September 2016. The standard deviation value in the ATV test was 11,

\section{b. Google search intensity}

Google search intensity is measured using the Abnormal Search Volume Index (ASVI) proxy. Based on the results of descriptive statistical tests, the average value of ASVI is 0.682 which means it is smaller than the standard deviation of 1.6265 , this explains that the ASVI average value has a high deviation rate and the data is heterogeneous. The maximum value of ASVI is 9,957 which occurred in BCA in April 2017, this happened because the intensity of searches using the BBCA ticker was higher than the average value of searches in the previous 12 months, namely 85 searches conducted in April compared to 63 searches in the previous 12 months. 12 months earlier. The minimum value of $-4,052$ was found at Bank Maya in September 2016,

\section{c. Volatility}

Based on the results of descriptive statistical tests the average value of volatilityis 0.013 and the standard deviation is 0.0262 which indicates that the data from volatility has a high deviation. The maximum value of 0.2379 was found in the China Construction bank in June 2016, the high value of volatility was caused by the high opening price of shares of 216 compared to the closing value of only 159 shares and the large difference between the highest value and the lowest value, which was 216 compared to 103 . For the minimum value of 0 was found in Mayapada bank in May and June 2018, this happened because Mayapada bank's stock price was stagnant at 3726.12 per share.

\section{d. Abnormal trading volume lagged-1 (T-1) ATV}

Based on the results of descriptive statistical tests, the average value of ATV t- 1 is -0.5112 with a standard deviation of 2,2500 , this shows the average value is below the standard deviation and explains that the data on ATV t-1 has a high deviation. . The maximum ATV t-1 value of 3.5017 was found at Maybank bank in July 2016 which was due to the high trading volume of Maybank shares in June 2016 of 785,096,637 compared to the previous 12 months average of 205,267.263. Minimum value

\section{IV.2 Panel Data Regression Test Results}

Table IV.2 Langrange Multiplier Test Results

Lagrange multiplier (LM) test for panel data

Date: 21/10/21 Time: 21:45

Sample: 2016M01 2018M12

Total panel observations: 648

probability in()

\begin{tabular}{llll}
\hline \hline $\begin{array}{l}\text { Null (no rand. effect) } \\
\text { Alternative }\end{array}$ & $\begin{array}{l}\text { Cross-section } \\
\text { one-sided }\end{array}$ & $\begin{array}{l}\text { Period } \\
\text { one-sided }\end{array}$ & Both \\
\hline \hline Breusch-Pagan & $\begin{array}{lll}1.276592 \\
(0.2585)\end{array}$ & $\begin{array}{l}0.194055 \\
(0.6596)\end{array}$ & $\begin{array}{l}1.470646 \\
\text { Honda }\end{array}$ \\
& -1.129864 & -0.440517 & -1.110426 \\
King-Wu & $(0.8707)$ & $(0.6702)$ & $(0.8666)$ \\
& -1.129864 & -0.440517 & -1.178829 \\
GHM & $(0.8707)$ & $(0.6702)$ & $(0.8808)$ \\
& -- & -- & 0.000000 \\
\hline \hline
\end{tabular}

Source: Data processed by researchers using

Based on table IV.2 the probability value of Breusch-Pagan is 0.2585 , which means the value is $>0.05$. It can be concluded that in the tests carried out with the Langrange Multiplier accept $\mathrm{H} 0$ and reject $\mathrm{H} 1$, then the best model that can be used in this study is the Common Effect Model.

\section{IV.3 Classical Assumption Test}

\section{a. Multicollinearity Test}

In this study, the variables tested for multicollinearity were ASVI, Volatility, and ATV t-1. The following are the results of the multicollinearity test: 
The Influence of Google Search Intensity on the Stability of the Indonesian Capital Market in the Perspective of the Defense Economy

Table IV.3 Multicollinearity Test Results

\begin{tabular}{llll}
\hline \hline VARIABLE & ASVI & VOLATILITY & ATV_T_1 \\
\hline \hline ASVI & 1.0000000 & 0.072409 & 0.310020 \\
VOLATILITY & 0.072409 & 1.0000000 & 0.149559 \\
ATV_T_1 & 0.310020 & 0.149559 & 1.0000000 \\
\hline \hline
\end{tabular}

Source: Data processed by researchers using views 10

From the data generated by the multicollinearity test, as table IV.3 shows that there is no variable whose value is more than 0.9. So it can be said that in this study there was no multicollinearity between the independent variables and the control variables.

\section{b. Autocorrelation Test}

Autocorrelation is a correlation between one residual and another residual. While one important assumption in research using the common effect model is the insignificant correlation of one residual with the other residuals. In the Durbin-Watson table, this study has 18 research objects (n) and 4 variables (K), so that the DL value is 0.93310 and DU is 1.69614 . Based on table IV.5 the regression results after there is a control variable, the results of DW are 2.11982. So that the value of DW is between DU ( 1.69614) $<$ DW (2.11982) < 4-DU ( 4-1.1.69614 = 2.30386). So it can be concluded that in this study there is no autocorrelation

\section{c. Regression Test}

1) Regression test results before there is a control variable

In the regression test before there was a control variable, it only saw the effect of the independent variable, namely ASVI on the dependent variable, namely ATV. The results of the regression before there was a control variable were as follows:

\section{Table IV.4 Regression Test Results Before There is a Control Variable}

Dependent Variable: ATV

Method: Least Squares Panel

Dates: 21/10/21Time: 23:07

Sample: 2016M01 2018M12

Periods included: 36

Cross-sections included: 18

Total panel (balanced) observations: 648

\begin{tabular}{lllll}
\hline \hline Variable & Coefficient & Std. Error & t-Statistic & Prob. \\
\hline \hline C & -0.029310 & 0.466791 & -0.062790 & 0.9500 \\
ASVI & 0.882605 & 0.260800 & 3.384220 & 0.0008 \\
\hline \hline R-squared & 0.017420 & Mean dependent var & 0.572326 \\
Adjusted R-squared & 0.015899 & SD dependent var & 11.07545 \\
SE of regression & 10.98705 & Akaike info criterion & 7.634394 \\
Sum squared resid & 77982.12 & Schwarz criterion & 7.648202 \\
Likelihood logs & $-2471,544$ & Hannan-Quinn Criter. & 7.639751 \\
F-statistics & 11.45295 & Durbin-Watson stat & 2.072267 \\
Prob(F-statistic) & 0.000757 & & \\
\hline \hline
\end{tabular}

Source: Data processed by researchers using views 10

Based on table IV.4 it can be seen that the results of the regression test show that the probability value of ASVI is 0.0008 which means $<0.05$. With these results, it can be concluded that $\mathrm{H} 0$ is rejected, and explains the effect of Google search intensity as proxied by ASVI on stock liquidity as proxied by ATV.

2) Regression test results after there is a control variable

In the regression test after there is a control variable, all independent variables and control variables are regressed simultaneously. The results of the regression test after there is a control variable are as follows: 
The Influence of Google Search Intensity on the Stability of the Indonesian Capital Market in the Perspective of the Defense Economy

Table IV.5 Regression Test Results After There is a Control Variable

Method: Least Squares Panel

Dates: 21/10/21Time: 15:12

Sample: 2016M01 2018M12

Periods included: 36

Cross-sections included: 18

Total panel (balanced) observations: 648

\begin{tabular}{lllll}
\hline \hline Variable & Coefficient & Std. Error & t-Statistic & Prob. \\
\hline \hline C & -0.103925 & 0.534663 & -0.194376 & 0.8459 \\
ASVI & 0.511429 & 0.269106 & 1.900477 & 0.0378 \\
VOLATILITY & 52.82982 & 16.34100 & 3.232962 & 0.0013 \\
ATV_T_1 & 0.737467 & 0.199811 & 3.690817 & 0.0002 \\
\hline \hline R-squared & 0.058042 & Mean dependent var & 0.572326 \\
Adjusted R-squared & 0.053654 & SD dependent var & 11.07545 \\
SE of regression & 10,77424 & Akaike info criterion & 7.598346 \\
Sum squared resid & 74758,20 & Schwarz criterion & 7.625963 \\
Likelihood logs & $-2457,864$ & Hannan-Quinn Criter. & 7.609060 \\
F-statistics & 13,22737 & Durbin-Watson stat & 2.119826 \\
Prob(F-statistic) & 0.000000 & & \\
\hline \hline
\end{tabular}

Source: Data processed by researchers using views 10

In table IV.5 after being regressed together with the control variable the probability of ASVI is 0.0378 which means it has an effect on ATV. The control variables Volatility and ATV t-1 have probability values of 0.0013 and 0.0002 which are <0.05, it can be concluded that there is an effect of Volatility and ATV t-1 on ATV. Based on the results of the regression test, the following equation can be made:

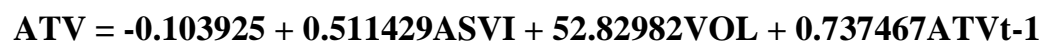

\section{CONCLUSIONS AND SUGGESTIONS}

\section{V.1 Conclusion}

In the process of searching for information related to stocks in the banking sector, Google is expected to become a search engine for investors to access information as a reference for conducting stock transactions on the Indonesia Stock Exchange. Technological developments make information patterns change, including information patterns in the banking sector, this is the reason researchers choose samples in the banking sector. This study aims to see the level of capital market stability seen from the liquidity aspect which is influenced by the intensity of Google searches, using the abnormal search volume index (ASVI) proxy for stock liquidity proxied by the abnormal trading volume (ATV) of banking companies listed on the Stock Exchange for the period 2016 -2018. Based on the research that has been carried out, it can be concluded that the intensity of Google searches proxied by ASVI has a significant positive effect on Stock Liquidity proxied by Abnormal Trading. The volume of shares of banking sector companies listed on the Indonesia Stock Exchange for the 2016-2018 period. This illustrates that to deal with non-military threats related to data manipulation published on the Google search engine, the government must control it so that there is no crime that disrupts capital market stability caused by investors in making decisions using invalid references.

\section{V.2 Implication}

Based on the results of research on the effect of Google search intensity on stock liquidity in the banking sector listed on the IDX for the 2016-2018 period, this study has practical implications that explain for investors, especially individual investors who invest without using an investment manager, starting to consider the use of historical data Google Trends. actively as a technical analysis in seeing how the activity of shares in the Indonesian stock exchange. In this study ASVI as the independent variable, VOL and ATVt-1 as control variables have a significant positive effect on stock liquidity, meaning that these variables are important to be considered by investors in making investment decisions and companies in increasing the company's stock liquidity.

\section{V.3 Suggestions}

Here are some suggestions that the author gives for further research: 


\section{The Influence of Google Search Intensity on the Stability of the Indonesian Capital Market in the Perspective of the}

Defense Economy

1. Can extend the sample period used. This is done in order to increase accuracy and see the attention of investors in seeking stock information over a longer period of time.

2. Can use case studies with other industrial sectors, such as retail, which is experiencing the process of digitizing information and has good prospects for the public and investors.

3. To see a broader influence and to see the characteristics of the stock market in responding to information, a comparative study can be conducted with the stock markets of other countries.

4. Can use other proxies such as bid-ask spread in calculating stock market stability and see its effect on investors' attention in seeking information. For the intensity of searching for information itself, you can use other proxies such as the yahoo index.

5. More in-depth research is needed related to non-military threats to the capital market sector in addition to the threat of data manipulation crimes for investment.

\section{REFERENCE}

1) Adachi, Yuta., Masuda, Motoki and Takeda, Fumiko. 2017. Google search intensity and its relationship to the returns and liquidity Japanese Startup Stocks. Pacific-Basin Finance Journal Vol. 46, p. 243-257

2) Arbel, A., Carvell, S., and Strebel, P. 1983. Giraffes, Institution and neglected firm. Cornel University,

3) Bade, M., and Hirth, H. (2016). Liquidity costs vs. real investment efficiency. Journal of Financial Markets, 28, 70-90. https://doi.org/10.1016/j.finmar.2015.10.001

4) Bank, M., Larch, M., and Peter, G. (2011). Google search volume and its influence on liquidity and returns of German stocks. Financial Markets and Portfolio Management, 25(3), 239-264. https://doi.org/10.1007/s11408-011-0165-y

5) Barber, Brad and Odean, Terrance. 2008. Financial Markets and Portfolio Management, Vol. 25, No. 3, pp. 239-264, 2011. Review of Financial Studies, 2008, vol. 21, issue 2, 785-818

6) Bijl, Laurens., Kringhaug, Glenn., Molnar, Peter and Sandvik, Eirik. 2016. Google search and stock returns. International Review of Financial Analysis Vol 45, p. 150-156

7) Brooks. 2008. Introductory econometrics for finance. Cambridge University Press, UK

8) Citra, 2017. Analysis of the Effect of Investor attention on Market Activity, Market Liquidity and Stock Market Volatility (Empirical Study LQ-45). Indonesia Banking School Journal, vol.14, No 2.

9) Conroy, Robert. 1990. The Effects of Stock Splits on Bid Ask Spreads. The Journal of Finance vol.45, No 4.

10) Da, ZHI, Engelberg, J., \& Gao, P. (2011). In Search of Attention. LXVI(5).

11) Daigler and Willey. 1999. The impact of trader type on the future volatility - volume relation. The Journal of Finance vol.54, No 6.

12) De Weerd. 2003. Attention Neural Basis of. Encyclopedia of cognitive science. Natural publishing group

13) Ding, R., and Hou, W. 2015, Retail Investor Attention and Stock liquidity. Journal of International Financial Markets, Institutions, and Money, vol 37, p. 12-26.

14) Drake, Michael. 2012. Investor Information Demand: Evidence from Google Searches Around Earnings Announcements. Journal of Accounting Research Vol. 4 No.3

15) Easley, D. and M. O'Hara. 1987. Price, Trade size, and Information in securities market. Journal of financial economics, 19, p. 69-90

16) Fama, Eugene. 1969. Efficient Capital Markets: A Review of Theory and Empirical Work. The Journal of Finance Vol. 25, No. 2 h. 383-417

17) Fang, Lily and Peress, Joel. 2009. Media Coverage and the Cross section of Stock Returns. The Journal of the American Finance Association. 96-102. https://doi.org/10.1016/j.frl.2017.10.025

18) Fehle, F. and Tsyplakov, S. 2005. Can Companies Influence Investor Behavior Through Advertising? Super Bowl Commercials and Stock Returns. European Financial Management Vol. 78 p.3-47

19) Garman, Mark and Klass, Michael. 1980. On the Estimation of Security Price Volatilities from Historical Data. The Journal of Business Vol. 53 issue 1 p.67-78

20) Glosten, Lawrence. and Harris, Lawrence. 1988. Estimating The Component Of The Bid Ask Spread. Journal of financial economics 21, p. 123-142

21) Gold, Nathan., Wang, Qiming., Cao, Melanie., and Huang, Huaxiong. 2017. Liquidity and Volatility commonality in the Canadian stock market. Mathematics in Industry Case Studies 8:7

22) Grullon, Gustavo. 2004. Advertising, Breadth of Ownership, and Liquidity. The Review of Financial Studies, Vol. 17 Issue 2 p. $439-461$

23) Gujarati, DN 2012. Basic Econometrics. New Delhi: Tata McGraw-Hill Education

24) Husnan, Suad. 2005. Fundamentals of Portfolio Theory and Securities Analysis. UPP AMP YKPN, Yogyakarta 
25) Kahneman, Daniel. 1973. Attention and effort. University of Michigan: Prentice-Hall

26) Kim, Neri., Lucivjanska, Katarina and Villa, Roviel. 2018. Google searches and stock market activity: Evidence from Norway. Finance Research Letters, 28 (November 2017), 208-220. https://doi.org/10.1016/j.frl.2018.05.003

27) Merton, Robert. 1987. A Simple Model of Capital Market Equilibrium With Incomplete Information. The Journal of Finance Vol. 3, pp. 1684

28) Nachrowi, Djalal Nachrowi and Hardius Usman. 2006. Popular and Practical Econometrics Approaches to Economic and Financial Analysis. Jakarta

29) Parkinson, M. 1980. The Extreme Value Method for Estimating the variance of the rate of return. Journal of Business Vol 53. pp. 61-65

30) Sewell, Martin. 2012. The Efficient Market Hypothesis: Empirical Evidence. International journal of statistics and probability, Vol 1.

31) Sojka, Barbara B., and Kliber, Agata. 2019. The Causality between liquidity and volatility in the Polish stock market. Finance research Letters, Vol 30, p. 110-115

32) Sugiyono. 2012. Quantitative, Qualitative and R\&D Research Methods. Bandung: Alphabeta

33) Takeda, Fumiko., and Wakao Takumi. 2013. Google search intensity and its relationship with return and trading volume of japanese stock. Pacific - Basin Finance Journal 27, p. 1-8

34) Wang, B., Long, W. and Wei, X. 2018. "Investor Attention, Market Liquidity and Stock Return: A New Perspective," Asian Economic and Financial Review, 8 (3), p. 341-352.

35) Xu, Yanyan., Huang, Dengshi., Ma, Feng., and Qiao, Gaoxiu. 2018. Liquidity and realized range base volatility forecasting: evidence from China. Physics A 525, p. 1102-1113.

36) Yang, ZH et al. 2017. "Quantifying the effect of investors' attention on the stock market," PLoS ONE, 12(5), p. 21-34.

37) Yusgiantoro, P. (2014). Defense Economics. Main Library Gramedia. Jakarta. 